$\mathbb{T}$ periodica polytechnica

Chemical Engineering

$51 / 2(2007) 6770$

doi: 10.3311/pp.ch.2007-2.11

web: http://www.pp.bme.hu/ch

(c) Periodica Polytechnica 2007

RESEARCH ARTICLE

\section{Recovery of vanadium, nickel and molybdenum from fly ash of heavy oil-fired electrical power station}

\author{
Jamal Stas / Ajaj Dahdouh / Omar Al-chayah
}

Received 2006-10-11

\begin{abstract}
After some preliminary tests, two leaching stages of fly ash to recover vanadium, molybdenum and nickel were selected. A first stage was an alkaline leaching of fly ash to recover vanadium and molybdenum followed by a second stage using sulfuric acid leaching of the residual ash to recover nickel.

The impact of some operational parameters (liquid/solid, leaching temperature, mixing time, and agent leaching concentrations) on the recovery of $\mathrm{V}, \mathrm{Ni}$ was investigated.

Conditions of precipitation of $V$ and Mo from alkaline medium and Ni from sulfuric acid solution were established.
\end{abstract}

\section{Keywords}

fly ash $\cdot$ leaching $\cdot$ vanadium $\cdot$ nickel $\cdot$ molybdenum

\section{Acknowledgement}

The authors wish to express their gratitude to Dr I. Othmanm, General Director of Syrian Atomic Energy Commission, for encouragement and support and to Dr G. Zayzafoon, head of Chemistry Department for his valuable comments.

\section{Jamal Stas}

Ajaj Dahdouh

\section{Omar Al-chayah}

Department of Chemistry, Atomic Energy Commission,, P.O.Box 6091 Damascus, Syria

\section{Introduction}

Two fundamental reasons underline the interest of metals recovering from waste ash: First, reduction of pollution source. Metals as V, Ni, Mo,... . etc. were found to be leached out of the waste ash contaminating water and soil [1,2]. Second, the economic value of the recovered metals seems to be very attractive.

Many technological process have been proposed to recover $\mathrm{V}$, $\mathrm{Ni}, \mathrm{Mo}, \ldots$ etc. from fly ash, but most literature on this subject is in the form of patents [3, 4]. Each ash has its own identity, depending on the characteristics of the burned oil and the place of ash formation, which involves development of an appropriate treatment to recover such metals. Recovery of vanadium and nickel from fly ash can be achieved by acid [5.7], alkaline [8,-10] or water leaching [11,12].

A process was developed [5] at Canadian Petrofina Ltd. for large scale production of vanadium from fly ash, the process consists of leaching the fly ash with sulfuric acid to dissolve vanadium and filtrating the resulting slurry. The vanadium was separated from the filtrate by oxidizing to pentavalent state with sodium chlorate and precipitating with ammonia. The hydrated pentoxide was dried, fused and cast into flakes. The author does not indicate any solution purification operation that leads to $99 \%$ of pure pentoxide.

Other authors [8] consider that acid leaching is inefficient for vanadium dissolution and they propose an alkaline leaching using a high concentration of $\mathrm{NaOH}$ that gives about $94 \%$ of vanadium recovery. After vanadium recovery, the remaining ashes contain $15 \%$ nickel; the latter can be recovered by leaching with $30 \% \mathrm{H}_{2} \mathrm{SO}_{4}$.

H. Ottartun [13] used $\mathrm{H}_{2} \mathrm{SO}_{4}$ coming from the solvent unit extraction to leach the ash. During leaching, vanadium is kept in its tetravalent state by feeding $\mathrm{SO}_{2}$ to the solution. Solvent extraction of $\left(\mathrm{V}^{+4}\right)$ is performed with $20 \%$ di-(2-ethylhexyl) phosphoric acid and $15 \%$ tributylphosphate. The raffinate is returned to the leaching stage.

Our main objective is to systematically investigate the optimum conditions of $\mathrm{V}$, Mo and Ni recovery from fly ash produced from heavy oil-fired electrical power stations, which gives the best yield of leaching and purity of the final product. 


\section{Experimental}

Leaching agents used were orthophosphoric acid (85\%), sulfuric acid (96\%), perchloric acid (70\%) from Fluka, nitric acid (65\%) from Merck, ammonium sulfate (99\%) from Sharlau, sodium hydroxide (99\%) from Analr and sodium carbonate (99\%) from Prolabo. Mineral composition of the solutions obtained by digestion of the fly ashes was determined by AAS vario6 (Analytik jena).

Fly ashes were collected from Damascus thermal power station between the radiant furnace and the stack (local temperature 160 to $180^{\circ} \mathrm{C}$ ); the thermal power station is not fitted with an electrostatic precipitator. Prior to leaching, a mass of ash was ground and mixed during 12 hours time to render the solid homogeneous. Three samples from this mass were digested at the same conditions and analysed to determine the mineral composition of the fly ash and verify the homogeneity of the ground ash. Results are shown in Table 1.

Tab. 1. Chemical composition of raw fly ash

\begin{tabular}{lcccc}
\hline Elements & $\begin{array}{c}\text { First sample } \\
\text { (wt.\%) }\end{array}$ & $\begin{array}{c}\text { Second sample } \\
\text { (wt.\%) }\end{array}$ & $\begin{array}{c}\text { Third sample } \\
\text { (wt.\%) }\end{array}$ & $\begin{array}{c}\text { Mean } \\
\text { (wt.\%) }\end{array}$ \\
\hline Moisture & 0.166 & 0.156 & 0.160 & 0.16 \\
$\mathrm{~V}$ & 5.02 & 5.03 & 4.95 & 5 \\
$\mathrm{Ni}$ & 1.56 & 1.52 & 1.54 & 1.54 \\
$\mathrm{Mo}$ & 0.34 & 0.35 & 0.36 & 0.35 \\
$\mathrm{Fe}$ & 22.22 & 22.05 & 21.9 & 22.05 \\
$\mathrm{Cr}$ & 0.8 & 0.78 & 0.82 & 0.8 \\
$\mathrm{Mg}$ & 0.2 & 0.22 & 0.19 & 0.2 \\
$\mathrm{Co}$ & 0.02 & 0.025 & 0.023 & 0.22 \\
\hline
\end{tabular}

Preliminary tests were performed to provide information about the best leachant for recovering $\mathrm{V}$ and $\mathrm{Ni}$ from the ash. Leaching was carried out at reflux temperature for 4 hours using either: water, phosphoric acid, nitric acid, hydrochloric acid, perchloric acid sulfuric acid or sodium hydroxide. The leachant concentration was $8 \mathrm{M}$, the temperature $100^{\circ} \mathrm{C}$ and liquid to solid ratio was 4 . The slurry was filtered and the filtrate was analysed by A.A.S.

Table 2 shows that acids leaching are effective but non selective process for vanadium dissolution. In fact the final leaching solution is accompanied by many other impurities. On the other hand alkali leaching of vanadium is effective and selective process, where only vanadium and molybdenum were dissolved by the alkali.

\section{Results and Discussion}

In order to obtain a high selectivity and yield of vanadium and nickel recovery, two leaching stages process of fly ashes were carried out.

1.First stage leaching with sodium hydroxide to leach out $\mathrm{V}$ and Mo from fly ash

Preparatory tests were performed to establish the best leaching operational parameters (Temperature, mixing time, liq-
Tab. 2. Effect of different leaching agents on the recovery of $\mathrm{V}$ and $\mathrm{Ni}$

\begin{tabular}{lllll}
\hline Leaching agent & V\% & $\mathrm{Ni} \%$ & $\mathrm{Mo} \%$ & $\mathrm{Fe} \%$ \\
\hline $\mathrm{H}_{2} \mathrm{O}$ & 35.5 & 42.9 & 3 & 57.9 \\
$\mathrm{H}_{3} \mathrm{PO}_{4}$ & 59.64 & 85.8 & 34 & 79.2 \\
$\mathrm{HNO}_{3}$ & 50.36 & 75.44 & 52 & 79.6 \\
$\mathrm{HCl}$ & 58.6 & 86.22 & 56 & 81.55 \\
$\mathrm{HClO}_{4}$ & 66.2 & 75.4 & 48 & 2.73 \\
$\mathrm{H}_{2} \mathrm{SO}_{4}$ & 66.26 & 91.01 & 54 & 2.91 \\
$\mathrm{NaOH}$ & 77 & 0.01 & 54 & 0 \\
\hline
\end{tabular}

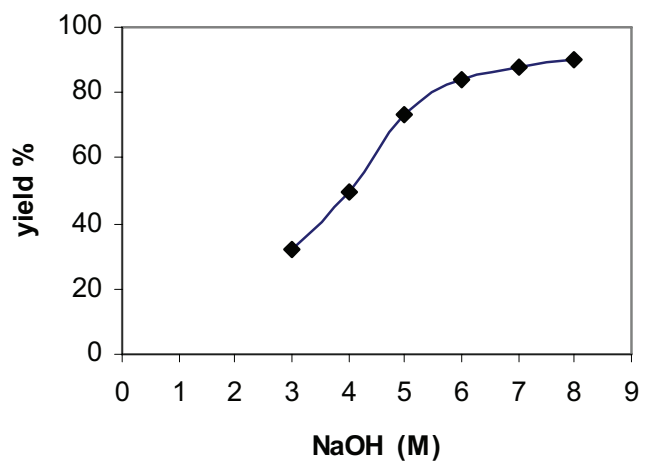

Fig. 1. Effect of $\mathrm{NaOH}$ concentration on vanadium recovery $(\mathrm{L} / \mathrm{S}=5, \mathrm{t}=4 \mathrm{~h}$, $\left.\mathrm{T}=100^{\circ} \mathrm{C}\right)$

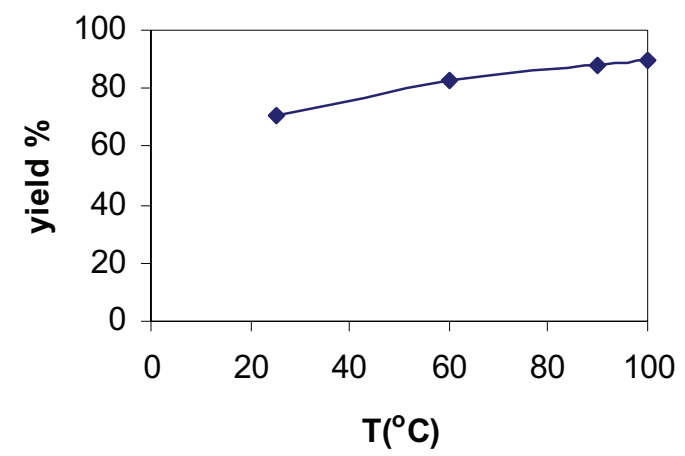

Fig. 2. Effect of temperature on vanadium recovery $([\mathrm{NaOH}]=8 \mathrm{M}, \mathrm{L} / \mathrm{S}=5$, $\mathrm{t}=4 \mathrm{~h})$

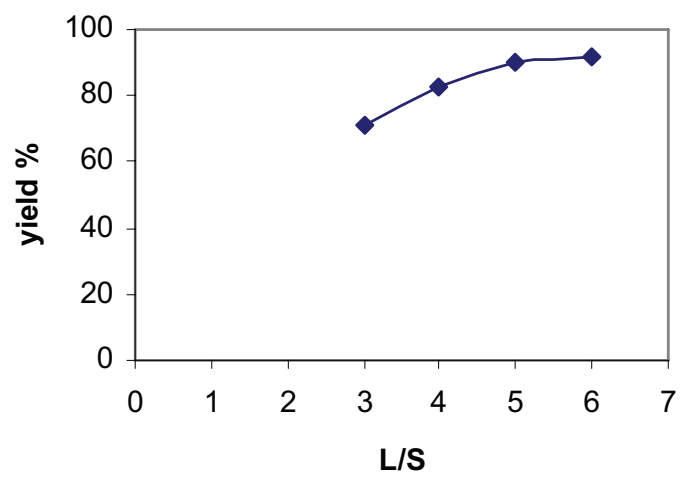

Fig. 3. Effect of liquid/solid ratio on vanadium recovery $([\mathrm{NaOH}]=8 \mathrm{M}$, $\left.\mathrm{t}=4 \mathrm{~h}, \mathrm{~T}=100{ }^{\circ} \mathrm{C}\right)$ 


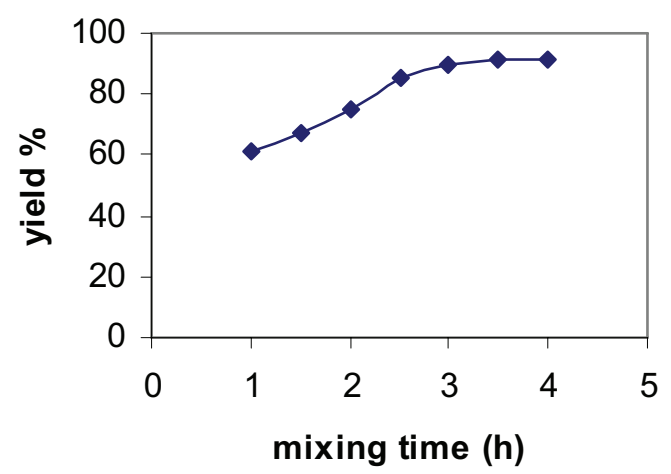

Fig. 4. Effect of mixing time on vanadium recovery $([\mathrm{NaOH}]=8 \mathrm{M}, \mathrm{L} / \mathrm{S}=5$, $\left.\mathrm{T}=100{ }^{\circ} \mathrm{C}\right)$

$\operatorname{uid}(\mathrm{mL}) / \operatorname{solid}(\mathrm{g})$ ratio $(\mathrm{L} / \mathrm{S})$, and sodium hydroxide concentration). From Figs. 1, 2, 3, 4, we conclude that the best operating conditions to obtain high yield of $\mathrm{V}$ recovery and good concentration of $\mathrm{V}$ in the leach liquor is: $([\mathrm{NaOH}]=8 \mathrm{M}, \mathrm{L} / \mathrm{S}=5, \mathrm{~T}=$ $100{ }^{\circ} \mathrm{C}$, mixing time $=3 \mathrm{~h}$ ). Leaching efficiency was more than $85 \%$.

A block diagram for recovery of vanadium and molybdenum from fly ash is given in Fig. 5. Fly ash was leached with $8 \mathrm{M}$ sodium hydroxide to dissolve vanadium and molybdenum, at $100^{\circ} \mathrm{C}$ and liquid to solid ratio equals to 5 . After 3 hours of mixing the slurry was filtered and the residual ashes were sent to the second stage leaching. The final leaching solution containing vanadium and molybdenum was cooled to $5{ }^{\circ} \mathrm{C}$ for 1 hour under mild agitation; alkali-precipitate containing vanadium and trace of molybdenum was precipitated. The precipitate was separated from the leach solution by filtration. More than $90 \%$ of the leached vanadium was precipitated, while the filtrate containing sodium molybdate was acidified with $30 \%$ nitric acid to adjust the $\mathrm{pH}$ to 1 and heated to $80-90{ }^{\circ} \mathrm{C}$. Molybdenum was precipitated from the filtrate as molybdic acid $\left(\mathrm{H}_{2} \mathrm{MoO}_{4}\right)$.

In order to produce $\mathrm{V}_{2} \mathrm{O}_{5}$, the sodium vanadate was dissolved in $5 \% \mathrm{HNO}_{3}$ to get a solution with a $\mathrm{pH}=8$, solid ammonium sulfate was added to the solution. Ammonium meta vanadate produced was precipitated, separated by filtration and decomposed at $500{ }^{\circ} \mathrm{C}$ for 24 hours to yield vanadium pentoxide of purity of $99 \%$.

\section{Second Stage Leaching with Sulfuric Acid Solution}

After the vanadium and molybdenum recovery, the remaining ashes still contain some $15 \%$ of nickel; the latter can also be recycled by leaching with sulfuric acid solution. Some preliminary tests were carried out to study the effect of temperature, mixing time, $\mathrm{L} / \mathrm{S}$ ratio, and the sulfuric acid concentration on acidic leaching. From Figs. 6, 7, 8, 9 we conclude that the best operating conditions to obtain $80 \%$ of nickel recovery are:

$\left[\mathrm{H}_{2} \mathrm{SO}_{4}\right]=5 \mathrm{M}, \mathrm{T}=100^{\circ} \mathrm{C}, \mathrm{t}=3 \mathrm{~h}, \mathrm{~L} / \mathrm{S}=4$.

A block diagram for recovery of $\mathrm{Ni}$ from the residual ashes is given in Fig. 10. The residual ash coming from the first leaching stage was leached for a second time with $8 \mathrm{M}$ sulfuric acid solution at $100{ }^{\circ} \mathrm{C}$, liquid/solid ratio was 4 . After 4 hours of mixing

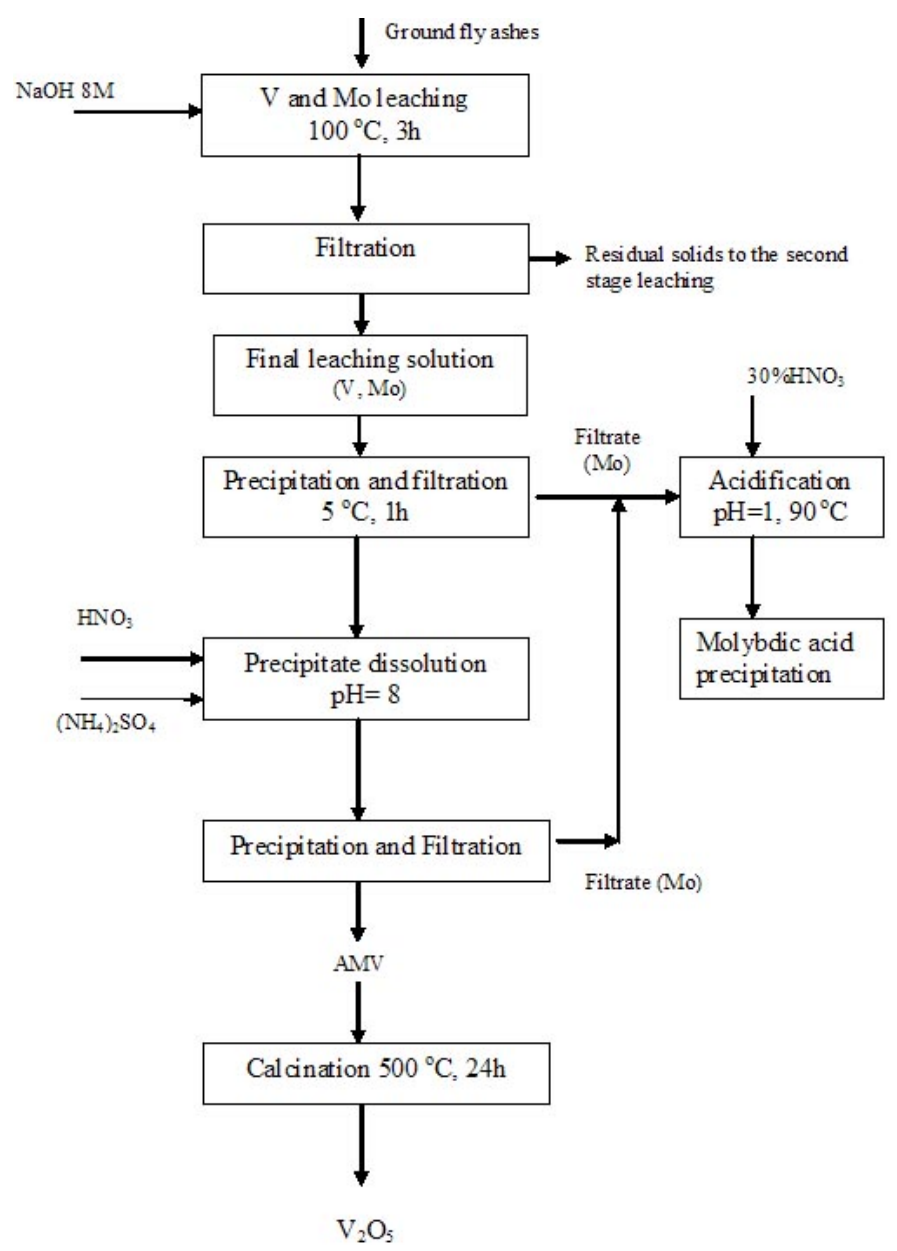

Fig. 5. First stage leaching to recover $\mathrm{V}$ and Mo

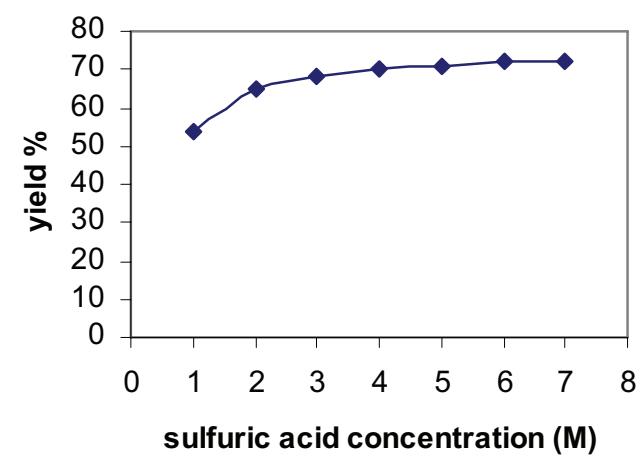

Fig. 6. Effect of $\mathrm{H}_{2} \mathrm{SO}_{4}$ concentration on nickel recovery $(\mathrm{L} / \mathrm{S}=3, \mathrm{t}=4 \mathrm{~h}$, $\mathrm{T}=100^{\circ} \mathrm{C}$ )

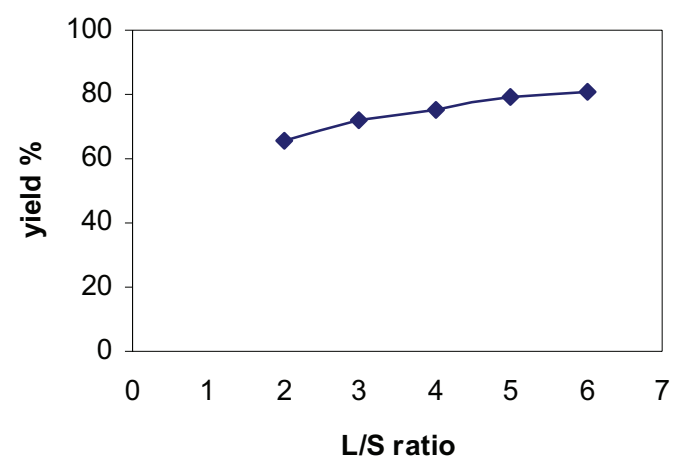

Fig. 7. Effect of liquid/solid ratio on nickel recovery $\left(\left[\mathrm{H}_{2} \mathrm{SO}_{4}\right]=5 \mathrm{M}, \mathrm{t}=4 \mathrm{~h}\right.$, $\mathrm{T}=100^{\circ} \mathrm{C}$ ) 


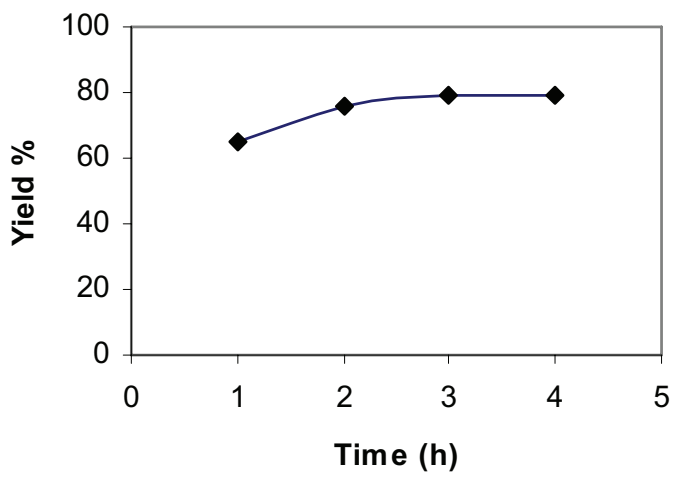

Fig. 8. Effect of mixing time on nickel recovery $\left(\left[\mathrm{H}_{2} \mathrm{SO}_{4}\right]=5 \mathrm{M}, \mathrm{L} / \mathrm{S}=5\right.$, $\mathrm{T}=100^{\circ} \mathrm{C}$ )

the slurry was filtered, the $\mathrm{pH}$ was adjusted to 2 with $\mathrm{NaOH} 8 \mathrm{M}$. Vanadium, iron and some trace of nickel were precipitated and removed by filtration, the precipitate was treated with $8 \mathrm{M} \mathrm{NaOH}$ to dissolve vanadium and send it to the first stage leaching while the $\mathrm{pH}$ of the filtrate was adjusted to 6 with $8 \mathrm{M} \mathrm{NaOH}$. Iron and trace of vanadium and nickel were precipitated and separated by filtration and sent to the waste. Finally the $\mathrm{pH}$ of the filtrate was adjusted with $2 \mathrm{M}$ sodium carbonate to 7 , where more than $85 \%$ of the nickel was precipitated as $\mathrm{NiCO}_{3}$.

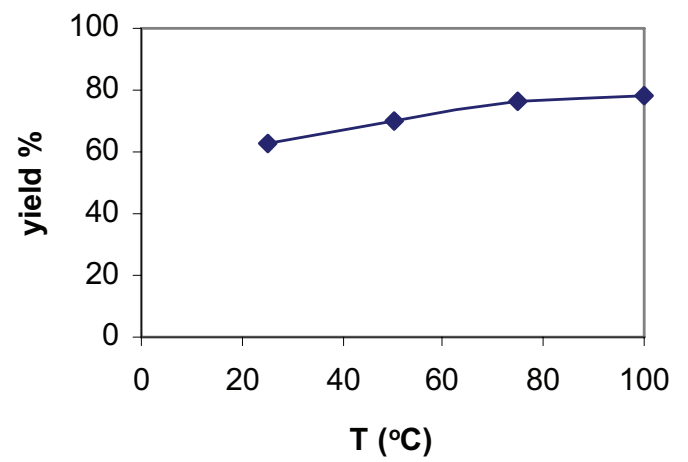

Fig. 9. Effect of temperature of nickel recovery $\left(\left[\mathrm{H}_{2} \mathrm{SO}_{4}\right]=5 \mathrm{M}, \mathrm{L} / \mathrm{S}=5\right.$, $\mathrm{t}=4 \mathrm{~h})$

\section{Conclusions}

The recovery of vanadium, nickel and molybdenum from fly ashes produced from heavy oil-fired electrical power station was achieved using two stages leaching process which consists of an alkaline leaching to dissolve vanadium and molybdenum followed by sulfuric acid leaching to recover nickel. The yield of vanadium recovery was more than $90 \%$ while nickel recovery was $80 \%$. A selective precipitation in stages has permitted to obtain a high purity of vanadium and nickel recovery. This process will be continuously examined later on a micro pilot scale.

\section{References}

1 Youngs W D, Rutzke M, Gutenmann WH, Lisk DJ, Nickel and vanadium in foliage in the vicinity of oil fired power plant, Chemosphere 27 (1993), no. $7,1269-1272$.

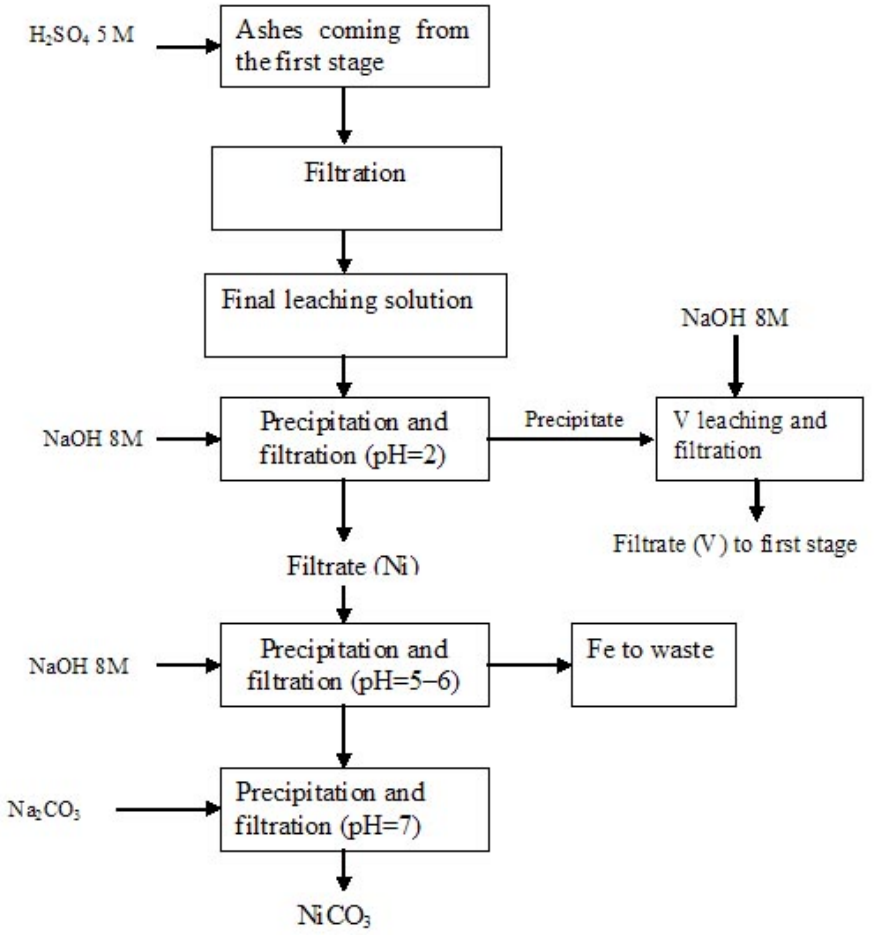

Fig. 10. Second stage leaching to recover nickel

2 Alvarez CE, Fernandez M, Perez N, Iglesias E, Snelling R, Effect of fly ash from a fuel oil power station on heavy metal content of wild plants At Tenrrife Island, the Canarian Archipelago, Spain, J. environ. SCI. health A28 (1993), no. 2, 269-283.

3 Schemel R, Rodrigues D, Salazar R, Method for leaching and recovering vanadium from vanadium bearing by-product materials (1985), no. U. S. patent $\mathrm{N}^{\circ} .4539186$.

4 Lakshmanan VI, Melnbardis D, Geisler RW, Process for treatment of fly ash (1989), no. U. S. patent $\mathrm{N}^{\circ} .4798709$.

5 Whigham W, New in extraction: Vanadium from petroleum, Chem. Eng 72 (1965), no. 5, 64-66.

6 Vitolo S, Seggiani M, Filpi S, Brocchini C, Recovery of vanadium from heavy oil and Orimulsion fly ashes, Hydrometallurgy 57 (2000), 141-149.

7 Parton G, Moretti G, Zingales A, Treatment of fine particulate (light ashes) from electrostatic precipitators of petroleum fired power plant, Riv. Combustion 47 (1993), no. 4, 169.

8 Chmielewski AG, Urbanski TS, Migdal W, Separation technologies for metals recovery from industrial wastes, Hydrometallurgy 45 (1997), 333 344

9 Edwards CR, The recovery of metal values from process residues, J. Mineral. 43 (1991), 32.

10 Tsuboi I, Kasai S, Kunugita E, Komosawa I, Recovery of gallium and vanadium from coal fly ash, J. Chem. Eng. 24 (1991), 15-20.

11 Gupta CK, Krishnamurthy N, Extractive Metallurgy of Vanadium, Elsevier Science, Netherlands, 1992. Chapter 3.

12 Akaboshi T, Kaneko N, Sakuma A, Sugiyama T, Recovery of ammonium metavanadate from petroleum-combustion residues, Jpn.Kokai Tokkio Koho JP 62 (1987), 298.

13 Ottartoun H, Strandell E, Solvent Extraction of Vanadium (IV) with Di-(2ethyl-hexyl) phosphoric Acid and Tributylphosphate, ISEC (1977), pp. 501508 . 